\title{
A SOBREVIVÊNCIA DA ESTÁTUA
}

\author{
André Piazera Zacchi \\ UFSC - CAPES
}

\begin{abstract}
RESUMO: No poema de Manuel Bandeira o cacto é uma estátua. Essa estátua tomba e interrompe a vida na cidade. Na morte o cacto se historiciza e, nesse sentido, ganha vida. A montagem das imagens no poema e sua leitura vertical, livre, nos apontam para outras imagens como as da escultura negra de Carl Einstein e sua leitura por Chris Marker e Alain Resnais em As estátuas também morrem, ou imagens como as poses dos nativos em ;Que viva México! de Eisenstein. A morte revolucionária e a intratabilidade fazem do cacto uma estátua sobrevivente.
\end{abstract}

PALAVRAS-CHAVE: Cacto; Estátua; Bandeira.

\section{SURVIVAL OF THE STATUE}

ABSTRACT: In Manuel Bandeira's poem the cactus is a statue. This statue falls and interrupts life in the city. In its death, the cactus becomes historicized and, in this sense, comes alive. The montage of the poem's images and its vertical and free reading evoke other images such as those of Carl Einstein's black sculpture in Negerplastik, those about black art in The statues also die by Chris Marker and Alain Resnais, or even those posed images as sculptures in ¡Que viva México! by Eisenstein. Revolutionary death and intractability make the cactus a surviving statue.

KEYWORDS: Cactus; Statue; Bandeira.

André Piazera Zacchi é doutorando do Programa de Pós-Graduação em Literatura da Universidade Federal de Santa Catarina. 


\section{A SOBREVIVÊNCIA DA ESTÁTUA}

\section{André Piazera Zacchi}

Manuel Bandeira faz do cacto uma estátua. Estátua que lembra, que evoca, que demanda outras imagens. Por isso o cacto é uma imagem: sempre dá mais do que aparece à vista, sempre pede mais investimento. A montagem evocativa, sugerida por Bandeira neste poema, demanda uma desdobra do que é lido ou imaginado. A leitura sequencial do poema $O$ Cacto (aquela leitura que busca enjambements), é interrompida pela cesura das linhas de versos livres. Nessas linhas, o poético se constrói pela tensão própria das imagens, pela montagem vertical que as põe em relação. ${ }^{1}$ Se tomarmos o poema como uma estátua, a leitura livre, salteada, vertical dos seus versos é como uma fissura no bloco de pedra, uma rachadura que abre (a estátua, o poema) ao arquivo, ao porvir. Convido o leitor ao Cacto de Bandeira:

\section{O CACTO}

Aquele cacto lembrava os gestos desesperados da estatuária:

Laocoonte constrangido pelas serpentes,

Ugolino e os filhos esfaimados.

Evocava também o seco nordeste, carnaubais, caatingas...

Era enorme, mesmo para esta terra de feracidades excepcionais.

Um dia um tufão furibundo abateu-o pela raiz.

O cacto tombou atravessado na rua,

Quebrou os beirais do casario fronteiro,

Impediu o trânsito de bondes, automóveis, carroças,

Arrebentou os cabos elétricos e durante vinte e quatro horas privou

[a cidade de iluminação e energia:

- Era belo, áspero, intratável. ${ }^{2}$

Mário de Andrade lembraria do poema em A poesia de 1930, publicada em 1931, texto no qual analisa quatro livros lançados no ano em questão. ${ }^{3}$ Dentre eles, Libertinagem, primeira vez que Bandeira publicaria em livro $O$

\footnotetext{
${ }^{1}$ EISENSTEIN, Sergei. O sentido do filme. Trad. Teresa Ottoni. Rio de Janeiro: Jorge Zahar Ed., 2002, p. 54.

2 BANDEIRA, Manuel. Libertinagem. In: Estrela da Manhã. Rio de Janeiro: Nova Fronteira, 2000, p. 06.

${ }^{3}$ ANDRADE, Mário. Aspectos da Literatura Brasileira. São Paulo: Martins, 1974, p. 27-45.
} 
cacto. Nesse texto, Mário diz que Bandeira é o cacto, pois seu ritmo, até então, era belo, áspero e intratável. Faz uma análise do uso do verso livre e o quanto isso tem relação com o que denomina indivíduo. No nome de Bandeira, entre o homem e o poeta, entre o texto biográfico e a obra, haveria uma luta permanente dessa intratabilidade do indivíduo contra o lírico que nele habita.

Davi Arrigucci Jr. faria uma análise detalhada do poema em A beleza humilde e áspera, texto no qual desenvolve suas hipóteses de leitura, publicadas no volume $O$ cacto $e$ as ruínas ${ }^{4}$ que também se dedica a Murilo Mendes, com o ensaio Arquitetura da memória. Quero destacar uma breve passagem de Arrigucci Jr. Nela, propõe uma relação de Bandeira com alguns outros modernistas e a certa vanguarda internacional, todos

marcados por um pendor semelhante pela forma despida, a drástica redução a uns poucos elementos compositivos, pela deformação da "figura" e por certa inclinação primitivista, que tivera sua origem no estudo da arte negra, em voga na Europa no princípio do século XX e provavelmente reativada pela presença entre nós do autor da Anthologie nègre, o poeta franco-suíço Blaise Cendrars. ${ }^{5}$

Então, para o crítico, a presença de Cendrars e o modismo de estudar a arte negra na Europa são correlatos da propensão de Bandeira a um certo primitivismo visto nos poemas da época de $O$ cacto, associado a uma redução de elementos de composição, a um despir da linguagem.

O estudo da arte negra teve como expoente, na mesma época de Cendrars, Carl Einstein, que publicaria em 1915 o ensaio Negerplastik. ${ }^{6}$ Tanto em Negerplastik, traduzido por "escultura negra" quanto em Anthologie nègre, ${ }^{7}$ considera-se a arte africana como efetivamente arte. O relato oral no caso de Cendrars, a escultura no caso de Einstein não deveriam ser tomados como curiosidade, dado etnográfico, religioso, ou analisados pelo viés de sua utilidade, mas vistos, intransitivamente, como arte, tão importante e, destaco, tão desenvolvida plasticamente quanto a arte europeia da época. Nada de primitiva, então.

\footnotetext{
${ }^{4}$ ARRIGUCCI JR., Davi. O cacto e as ruínas: a poesia entre outras artes. São Paulo: Duas Cidades; Ed. 34, 2000.

5 Ibidem, p. 29.

${ }^{6}$ EINSTEIN, Carl. Negerplastik (escultura negra). Org. Liliane Meffre. Trad. Fernando Scheibe e Inês de Araújo. Florianópolis: Ed. da UFSC, 2011.

7 CENDRARS, Blaise. Anthologie Nègre. Paris: Éditions de la Sirène, 1921.
} 
Esse argumento seria retomado por Alain Resnais e Chris Marker no filme de 1953 intitulado As estátuas também morrem. ${ }^{8}$ As estátuas que morrem, segundo a voz off que desliza sobre imagens de arte africana (de modo análogo à série de imagens que acompanham o texto do ensaio de Carl Einstein), são as esculturas que recebem um tratamento museológico que lhes nega porvir. Elas existem, como monumentos, duram no tempo, mas, benjaminianamente, não têm vida, não são mais capazes de história, ${ }^{9}$ pois são aprisionadas por um discurso cristalizador que impede sua transformação. Alguns discursos da arte negam tal devir, essa transformação, negando a história vindoura que é sempre feita de saltos anacrônicos. As estátuas morrem quando são naturalizadas e explicadas pelos discursos categorizantes da arte. É o que nos diz o filme, na esteira do pensamento de Carl Einstein.

A estátua e sua morte são os dois movimentos das duas primeiras estrofes do poema de Bandeira. O terceiro movimento, plasmado na terceira estrofe (de apenas um verso), é a sobrevivência da estátua, sua transformação, decorrente da historicidade vivida.

Escrito em Petrópolis em 1925, publicado na revista Estética no mesmo ano, o personagem Cacto é um imenso monumento desesperado, contorcido, como a famosa estátua de Laocoonte, na qual o protagonista defende a si e a seus filhos de uma serpente. O poema também compara "aquele cacto" (um cacto específico, que ele teria visto caminhando pela cidade, cacto urbano, de quintal) a outro conjunto escultórico, Ugolino e seus filhos, de Jean-Baptiste Carpeaux. As estátuas, separadas por aproximadamente 2.000 anos, têm íntima relação temática (o pai defendendo os filhos), mas especialmente plástica: Carpeaux declara ter usado como referência a composição de Laocoonte para esculpir o conjunto de Ugolino e seus filhos.

Ver os mesmos gestos no Cacto, em Laocoonte, em Ugolino. É o que Aby Warburg denominou fórmula de pathos e fazia circular em seus painéis, e que Bandeira reencontra na estatuária citada e coloca em uma série sucessiva. ${ }^{10} \mathrm{O}$

\footnotetext{
${ }^{8}$ Les statues meurent aussi. Filme de Chris Marker e Alain Resnais. Produtoras: Présence Africaine; Tadié Cinéma, 30min, P/B, 1953.

9 BENJAMIN, Walter. A tarefa do tradutor. In: Escritos sobre mito e linguagem. Trad. Susana Kampff Lages e Ernani Chaves. São Paulo: Duas Cidades / 34, p. 103 e ss.

${ }^{10}$ Aby Warburg propunha um gesto de leitura das imagens e de sua mise-en-scène em painéis, para nelas fazer circular o que denominava pathosformel. Encontrando tal formula que circulava entre imagens tão díspares e separadas no tempo, fomentava a sua sobrevivência. Além dos textos de Warburg, publicados no Brasil especialmente em A Renovação da Antiguidade pagã, pela editora Contraponto em 2013, recomendo de Georges Didi-Huberman, A imagem sobrevivente: história da arte e tempo dos fantasmas Segundo Aby Warburg, lançado recentemente pela mesma editor.
} 
cacto é uma estátua que compartilha com as outras duas o gestual desesperado do sofrimento. Na série de imagens do poema, ainda na primeira estrofe, temos o seco nordeste de carnaubais e caatingas e o tamanho monumental da planta. Os verbos no imperfeito sugerem uma continuidade no passado, uma duração anterior, uma ontologia duradoura, não-contingente.

O conjunto escultórico de Laocoonte recebeu muitas leituras, sendo talvez mais famosa a de Lessing. ${ }^{11}$ Mas Sergei Eisenstein também escreveria sobre Laocoonte, em 1937, para defender a tese de que uma imagem é, per se, sempre montagem, mesmo que não seja cinematográfica. ${ }^{12}$ Nesse ensaio, destaca a montagem de três afetos distintos e simultâneos no rosto esculpido de Laocoonte - expressão impossível para um rosto humano. A técnica, aduz, é cinematográfica, pois sugere uma série de tempos distintos na fixidez de uma mesma formalização plástica.

Eisenstein esteve no México entre 1930 e 1931. Lá filmou o povo nativo, suas manifestações culturais, mas dedicou maior interesse à questão composicional, que serve de premissa formal a iQue viva México!: ${ }^{13}$ de que maneira os rostos dos mexicanos e seu gestual mimetizam as formas dos monumentos astecas e as formas da vegetação (os cactos) que os cercam. O filme ficou perdido (ou foi abjurado pelo partido), depois recuperado e somente montado em 1979, conforme nos relata um dos diretores assistentes que, ao redescobrir o material, ficou incumbido da montagem conforme o projeto. O texto do prólogo havia sido escrito por Eisenstein e se inicia com a frase: "O tempo do prólogo é o tempo da eternidade". Nele, os rostos dos mexicanos são justapostos a esculturas e templos astecas, as imagens são poses em que os corpos estão em repouso, ou no máximo executam um gesto coreografado. Como se compusessem quadros, como se fossem personagens de uma tela, ou monumentos que rendem homenagem à relação entre a pedra, a vegetação, o povo, a morte e a vida, como nos segue dizendo o texto de Eisenstein em voz off. Os rostos são esculturas, os cactos são esculturas, o povo se faz escultura: eternidade e devir. Diante da colonização que lhes impõem os cultos católicos, Eisenstein devolve uma imagem de resistência colonial: para cumprir a penitência que mimetiza a subida de Cristo ao Calvário, em vez de carregarem nas

\footnotetext{
${ }^{11}$ LESSING, Gotthold Ephraim. Laocoonte, ou sobre as fronteiras da pintura e da poesia. Introdução, tradução e notas de Márcio Seligmann-Silva. São Paulo: Iluminuras, 1998.

12 EISENSTEIN. Sergei. Laocoön. In: Selected Works, Volume II: Towards a Theory of Montage. Trans. Michael Glenny. Londres / Nova lorque: I.B. Tauris, p. 106 e ss.

${ }^{13}$ iQue viva México!. Filme de Sergei Eisenstein, remontado segundo projeto inicial por Grigoriy Aleksandrov. 1h30, P/B, 1979.
} 
costas caibros de madeira, os nativos amarram-se espinhosos caules de cactos e re-encenam as três cruzes no Gólgota: pathosformel.

Na segunda estrofe do poema de Bandeira, o cacto, feito estátua na primeira, padece de um tufão furibundo, que o derruba. As estátuas também morrem, diríamos assim rapidamente. Mas, nesse caso, não é perda de devir descrita por Resnais e Marker sobre a arte negra. O poema é sensível a isso e faz, da morte, um gesto político, um acontecimento. O que toma conta dessa segunda parte é interrupção, a possibilidade de parar a máquina da produtividade citadina, o trânsito, a transmissão de energia. O cacto quebra, das casas burguesas, seus beirais, que é a exposição daqueles que tem eira e beira, ou seja, quebra a mise-en-scène colonial do capital. Walter Benjamin nos diria nas teses sobre o conceito de história que a revolução é correlata de uma explosão do continuum historicista. ${ }^{14} \mathrm{E}$, no fragmento teológico-político, que o tempo messiânico é o que põe termo à história humana opressora, pois faz devir do sofrimento felicidade. O cacto de Bandeira morre de morte revolucionária, seu sofrimento serve também para sabotar as engrenagens da apropriação capitalista da vida, da máquina de infelicidade.

Notemos a diferença dos tempos verbais da primeira e da segunda estrofe. Na primeira, os verbos estão no pretérito imperfeito: lembrava, evocava, era. $\mathrm{Na}$ segunda, temos os verbos no pretérito perfeito: abateu, tombou, quebrou, impediu, arrebentou. No imperfeito tem-se um dizer do ser do cacto, daquilo que tem duração no passado, sua estabilidade estatuária, a maneira pela qual o cacto toca a eternidade. Mas na segunda estrofe temos o ser do acontecimento, aquele que no passado, inesperadamente, surpreendentemente, contingencialmente, foi. A diferença ontológica entre os dois tempos do verbo ser: era e foi. O cacto era uma estátua, mas foi uma revolução.

Já o verso final, separado das duas estrofes anteriores, uma nova vida transformada do cacto: “ - Era belo, áspero, intratável." Agora são três características da personagem cacto num mesmo rosto, como o de Laocoonte, que sugere uma releitura do poema para encontrar, nas estrofes precedentes, tais feições. Uma releitura vertical das imagens. É como um pequeno galho que brota: o verso solto inicia uma terceira estrofe em porvir, anunciando, na intratabilidade do cacto, a difícil apropriação por uma narrativa de vida e morte. A intratabilidade do cacto é seu gesto de resistência, sua sobrevivência.

${ }^{14}$ BENJAMIN, Walter. Magia e técnica, arte e política. In: Obras escolhidas. v. II. Trad. Sergio Paulo Rouanet. São Paulo, Brasiliense, 1994, p. 222 e ss. 
Escrito três anos antes de $O$ cacto, também em versos livres, o poema Gesso acompanha a passagem de um nada vazio e morto à vida daquela estátua que sofreu, que tem história, tem afeto impregnado e porvir. De construção semelhante, mostra o que a estátua era, depois o que ela foi no acontecimento da queda, e da sobrevivência que adquire no jogo entre eternidade e contingência:

\section{GESSO}

Esta minha estatuazinha de gesso, quando nova - O gesso muito branco, as linhas muito puras Mal sugeria imagem de vida (embora a figura chorasse).

Há muitos anos tenho-a comigo.

O tempo envelheceu-a, carcomeu-a, manchou-a de pátina amarelo-suja.

Os meus olhos de tanto a olharem,

Impregnaram-na da minha humanidade irônica de tísico.

Um dia mão estúpida

Inadvertidamente a derrubou e partiu.

Então ajoelhei com raiva, recolhi aqueles tristes fragmentos,

Recompus a figurinha que chorava.

E o tempo sobre as feridas escureceu ainda mais o sujo

mordente de pátina...

Hoje esse gessozinho comercial

É tocante e vive, e me fez agora refletir

Que só é verdadeiramente vivo o que já sofreu. ${ }^{15}$

${ }^{15}$ BANDEIRA, Manuel. Estrela da vida inteira. 9. ed. Rio de Janeiro: J. Olympio, 1993, p. 54. 